\title{
PENGARUH UKURAN PARTIKEL DAN KOMPOSISI TERHADAP SIFAT KEKUATAN BENTUR KOMPOSIT EPOKSI BERPENGISI SERAT DAUN NANAS
}

\author{
Syahrinal Anggi Daulay, Fachry Wirathama, Halimatuddahliana \\ Departemen Teknik Kimia, FakultasTeknik,Universitas Sumatera Utara, \\ Jl. Almamater Kampus USU Medan 20155, Indonesia \\ Email : anggidaulay08007@gmail.com
}

\begin{abstract}
Abstrak
Penelitian ini bertujuan untuk mengetahui pengaruh ukuran partikel dan komposisi serat daun nanas terhadap sifat kekuatan bentur komposit epoksi berpengisi serat daun nanas. Komposit dibuat dengan metode hand lay up dengan mencampurkan epoksi dan pengisi serat daun nanas dengan variasi ukuran partikel 30 mesh, 40 mesh, 70 mesh, 100 mesh, dan rasio fraksi volum antara pengisi dan matriks 5/95, 10/90, 15/85 (v/v). Sifat mekanik yang diuji yaitu kekuatan bentur dan didukung dengan analisa SEM. Hasil yang diperoleh menunjukkan bahwa penambahan serat daun nanas pada komposit epoksi secara umum meningkatkan sifat kekuatan bentur komposit, dengan performa terbaik ditunjukkan variasi ukuran partikel 100 mesh dengan rasio 90/10 (v/v), dimana melalui analisa SEM menunjukkan penyebaran serat dengan ukuran partikel 100 mesh memiliki pendistribusian fasa pengisi yang lebih baik.
\end{abstract}

Kata kunci: serat daun nanas, epoksi, kekuatan bentur

\begin{abstract}
This research was aimed to investigate the effect of pineapple leafs particle size and pineapple leaf fiber composition of the impact strength of epoxy composites filled with pineapple leaf fibers. The composites were made by hand lay up method by mixing epoxy and pineapple leaf fiber with particle size variation of 30 mesh, 40 mesh, 70 mesh, 100 mesh, and volume fraction ratio between filler and matrix 5/95, 10/90, 15/85 (v/v). Mechanical properties wich tested was impact strength and supported with SEM analysis. The results obtained show that the addition pineapple leaf fiber as filler in epoxy composites generally increase the impact strength of the composites, with best performance shown by 100 mesh particle size variation with ratio 90/10 (v/v) which from SEM analysis show that this variation having better filler distribution.
\end{abstract}

Keywords: pineapple leaf fiber, epoxy, impact strength

\section{Pendahuluan}

Dalam dunia yang modern ini penggunaan material komposit mulai banyak dikembangkan dalam dunia industri manufaktur. Penggunaan material komposit yang ramah lingkungan dan bisa didaur ulang kembali, merupakan tuntutan teknologi saat ini. Salah satu komposit yang berkembang di dunia industri yaitu material komposit dengan pengisi (filler) baik yang berupa serat alami maupun serat buatan. Pada dasarnya material komposit merupakan gabungan dari dua atau lebih material yang berbeda menjadi suatu bentuk unit mikroskopik, yang terbuat dari bermacam-macam kombinasi sifat atau gabungan antara serat dan matrik. Saat ini bahan komposit yang diperkuat dengan serat merupakan bahan teknik yang banyak digunakan karena kekuatan dan kekakuan spesifik yang jauh di atas bahan teknik pada umumnya [8].

Epoksi termasuk kelompok polimer jenis termoset yang banyak digunakan sebagai bahan pelapis, perekat, dan sebagai matriks pada material komposit. Bahan ini sangat luas digunakan pada banyak aplikasi seperti automotif, aerospace, perkapalan, dan peralatan elektronik [9].

Adapun kelebihan epoksi ini dibandingkan dengan resin lain yaitu sifat mekanik dan termal yang tinggi, sangat tahan terhadap air, penyusutan sangat rendah, usia pakai lama, tahan temperatur hingga $220{ }^{\circ} \mathrm{C}$, daya tahan kimia dan stabilitas dimensi yang baik, sifat-sifat listrik yang baik, kuat dan daya lekat pada gelas dan logam yang baik [13]. Epoksi mengandung gugus - gugus kimia, diantaranya $\mathrm{C}=\mathrm{C}, \mathrm{O}-\mathrm{H}$ dan $\mathrm{C}-\mathrm{H}$ [12]. Adanya gugus $\mathrm{O}-\mathrm{H}$ mengindikasikan bahwa epoksi memiliki potensi untuk berinteraksi dengan gugus $\mathrm{O}-\mathrm{H}$ yang ada pada serat daun nanas.

Sementara itu, penggunaan serat alami sebagai pengisi/penguat pada bahan komposit disebabkan karena melimpahnya jenis tanaman penghasil serat, khususnya di Indonesia, sehingga membuat para peneliti tertarik untuk 
mengembangkan material komposit menggunakan bahan dari serat alam. Material komposit yang berasal dari serat alam kekuatannya tidak kalah dengan material komposit dari logam seperti aluminum [6].

Nanas atau Ananas comosus merupakan salah satu alternatif tanaman penghasil serat yang selama ini hanya dimanfaatkan buahnya sebagai sumber bahan pangan, sedangkan daun nanas dapat dimanfaatkan sebagai bahan penghasil serat tekstil [1]. Dari penelitian yang telah dilakukan oleh Mujiyono dan Didik [11], diperoleh bahwa serat daun nanas memiliki kekuatan tarik hampir dua kali lebih tinggi dibandingkan dengan fiberglass, yaitu 42,33 $\mathrm{kg} / \mathrm{mm}^{2}$ untuk serat daun nanas dan 21,65 $\mathrm{kg} / \mathrm{mm}^{2}$ untuk fiberglass. Dengan demikian serat daun nanas memiliki potensi untuk digunakan sebagai pengisi dalam suatu komposit.

Berdasarkan uraian di atas maka dilakukan kajian mengenai pemanfaatan serat daun nanas sebagai pengisi pada matriks resin epoksi dimana ukuran partikel serat dan komposisi serat dijadikan sebagai variabel untuk melihat karakter dari sifat ketahanan bentur yang dihasilkan dengan tujuan dapat menghasilkan bahan komposit yang memiliki sifat - sifat yang unggul / lebih baik.

\section{Teori}

Komposit adalah suatu material yang terbentuk dari kombinasi dua atau lebih material penyusunnya melalui proses pencampuran yang tidak homogen, dimana sifat mekanik dari masing-masing material pembentuknya berbeda. Komposit merupakan sistem multi fasa gabungan, yang menggabungkan bahan matriks (resin) sebagai pengikat dengan bahan lain sebagai fasa pengisi. Material komposit mempunyai sifat dari material konvensional pada umumnya, dari proses pembuatannya melalui proses percampuran yang tidak homogen, sehingga kita dapat dengan leluasa merencanakan kekuatan material komposit yang kita inginkan dengan jalan mengatur komposisi dari material pembentuknya. [10].

\section{Resin Epoksi}

Beberapa hal yang perlu diperhatikan dalam proses pencetakan komposit epoksi:

1. Mempunyai penyusutan yang kecil pada pengawetan.

2. Dapat diukur dalam temperatur kamar dalam waktu yang optimal.

3. Memiliki viskositas yang rendah yang dapat disesuaikan dengan material penyangga.

4. Memiliki kelengketan (sifat adesif) yang baik dengan material penyangga.
Resin epoksi mengandung struktur epoksi atau oxirene. Resin ini berbentuk cairan kental atau hampir padat, yang digunakan untuk material ketika hendak dikeraskan. Resin epoksi jika direaksikan dengan hardener yang akan membentuk polimer crosslink. Hardener untuk sistem curing pada temperatur ruang dengan resin epoksi pada umumnya adalah senyawa poliamida yang terdiri dari dua atau lebih grup amina. Curing time sistem epoksi sangat bergantung pada kereaktifan atom hidrogen dalam senyawa amina. Reaksi curing pada sistem resin epoksi terjadi secara eksotermis, berarti melepaskan sejumlah kalor saat proses curing berlangsung. Laju kecepatan proses curing bergantung pada temperatur ruang. Untuk kenaikan temperatur setiap $10{ }^{\circ} \mathrm{C}$, maka laju kecepatan curing akan menjadi dua kali lebih cepat, sedangkan untuk penurunan temperaturnya dengan besar yang sama, maka laju kecepatan curing akan turun setengah dari laju kecepatan curing sebelumnya. Epoksi memiliki ketahanan korosi yang lebih baik dari pada polyester pada keadaan basah, namun tidak tahan terhadap asam. Epoksi memiliki sifat mekanik, listrik, kestabilan dimensi dan penahan panas yang baik [2].

\section{Serat Daun Nanas}

Serat daun nanas adalah salah satu jenis serat alam yang berasal dari tumbuhan yang diperoleh dari daun tanaman nanas. Bentuk daun nanas menyerupai pedang yang meruncing diujungnya dengan warna hijau kehitaman dan pada tepi daun terdapat duri yang tajam. Tergantung dari spesies atau varietas tanaman, panjang daun nanas berkisar antara 55 sampai 75 $\mathrm{cm}$ dengan lebar 3,1 sampai $5,3 \mathrm{~cm}$ dan tebal daun antara 0,18 sampai $0,27 \mathrm{~cm}$.

Tabel 1 menunjukkan komposisi serat daun nanas dan beberapa serat alam lainnya.

Tabel 1. Komposisi Serat Daun Nanas dan Serat Alam lainnya [4]

\begin{tabular}{|c|c|c|c|}
\hline $\begin{array}{c}\text { Komposisi } \\
\text { Kimia }\end{array}$ & Nanas (\%) & Kapas (\%) & $\begin{array}{c}\text { Rami } \\
(\%)\end{array}$ \\
\hline $\begin{array}{c}\text { Alpha } \\
\text { Selulosa }\end{array}$ & $69,5-71,5$ & 94 & $72-92$ \\
\hline Pentosa & $17-17,8$ & - & - \\
\hline Lignin & $4,4-4,7$ & - & $0-1$ \\
\hline Pektin & $1-1,2$ & 0,9 & $3-27$ \\
\hline Wax & $3-3,3$ & 0,6 & 0,2 \\
\hline Abu & $0,71-0,87$ & 1,2 & 2,87 \\
\hline $\begin{array}{c}\text { Zat - zat } \\
\text { lain (protein, } \\
\text { asam } \\
\text { organik, dll) }\end{array}$ & $4,5-5,3$ & 1,3 & 6,2 \\
\hline
\end{tabular}


Proses pengambilan serat daun nanas pada umumnya dilakukan pada usia tanaman berkisar antara 1 sampai 1,5 tahun. Serat yang berasal dari daun nanas yang masih muda pada umumnya tidak panjang dan kurang kuat. Sedangkan serat yang dihasilkan dari tanaman nanas yang terlalu tua, terutama tanaman yang pertumbuhannya di alam terbuka dengan intensitas matahari cukup tinggi tanpa pelindung, akan menghasilkan serat dengan karakter yang pendek, kasar dan getas [4].

Adapun perbandingan sifat mekanis serat daun nanas dengan beberapa serat alam lainnya dapat dilihat pada Tabel 2 di bawah ini :

Tabel 2. Sifat - Sifat Mekanis Serat Alami [7]

\begin{tabular}{|c|c|c|c|}
\hline Serat & $\begin{array}{c}\text { Kekuatan } \\
\text { Tarik } \\
(\mathrm{MPa})\end{array}$ & $\begin{array}{c}\text { Elongasi } \\
(\%)\end{array}$ & $\begin{array}{c}\text { Kekerasan } \\
(\mathrm{MPa})\end{array}$ \\
\hline $\begin{array}{c}\text { Tanda } \\
\text { sawit }\end{array}$ & 248 & 14 & 2.000 \\
\hline $\begin{array}{c}\text { Mesocarp } \\
\text { sawit }\end{array}$ & 80 & 17 & 500 \\
\hline $\begin{array}{c}\text { Sabut } \\
\text { kelapa }\end{array}$ & 140 & 25 & 3.200 \\
\hline Pisang & 540 & 3 & 816 \\
\hline Sisal & 580 & 4,3 & 1.200 \\
\hline $\begin{array}{c}\text { Daun } \\
\text { nanas }\end{array}$ & $\mathbf{6 4 0}$ & $\mathbf{2 , 4}$ & $\mathbf{9 7 0}$ \\
\hline
\end{tabular}

\section{Metodologi \\ Bahan}

Epoksi diperoleh dari cabang PT. Justus Kimia Raya yang beralamat di Medan, dan serat daun nanas diperoleh dari CV. Hasanah Niaga yang beralamat di Tangerang.

\section{Prosedur Kerja}

Komposit dibuat dengan metode hand lay up dimana resin epoksi dan hardener dicampur dengan perbandingan $1: 1$, dan kemudian ditambahkan serat daun nenas yang sudah dihaluskan sesuai dengan ukuran partikel yang sudah ditentukan dengan rasio komposisi antara matriks dan pengisi yang telah ditentukan. Cetakan disiapkan dengan menggunakan lilin yang beralas kaca dan dilapis plastik tipis, kemudian lilin dibentuk sesuai dengan bentuk sampel pengujian ketahanan bentur sesuai dengan standar ASTM D 4812-11.

Kemudian tuang resin epoksi kedalam beaker glass diikuti dengan penambahan serat daun nanas dan diaduk selama 5 menit, setelah merata tambahkan hardener dan diaduk selama 3 menit. Selanjutnya tuangkan resin ke dalam cetakan dan ratakan bagian permukaannya, setelah rata komposit didiamkan selama 1 hari pada suhu ruangan. Setelah mengeras komposit dikeluarkan dari cetakan dan dihaluskan bagian permukaannya dengan menggunakan kertas pasir.
Selanjutnya dilakukan pengujian terhadap sifat ketahanan bentur komposit.

\section{Hasil dan Pembahasan}

\section{Karakteristik Kekuatan Bentur}

Gambar 1. menunjukkan pengaruh penambahan bahan pengisi serat daun nanas terhadap sifat ketahanan bentur komposit epoksi.

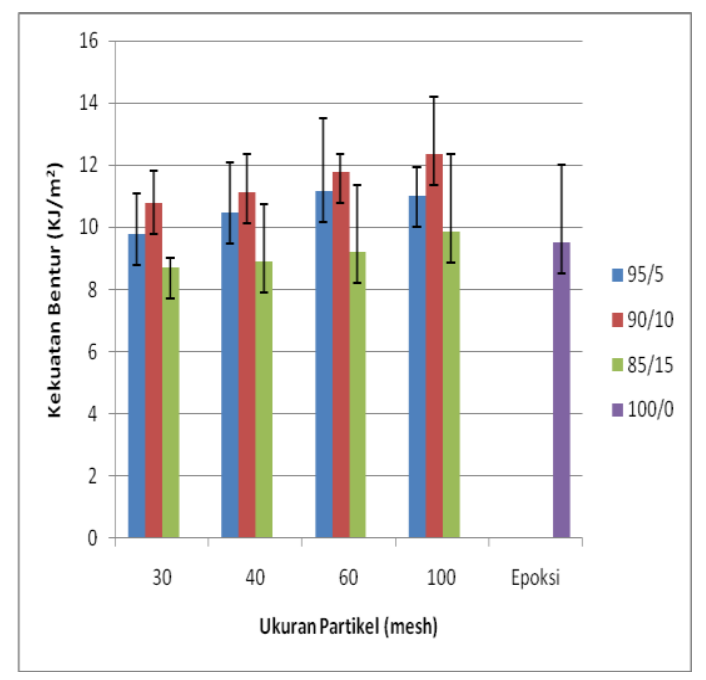

\section{Gambar 1. Hasil Pengujian Kekuatan Bentur}

Pada Gambar 1 dapat dilihat bahwa dengan penambahan bahan pengisi dari rasio matriks dan pengisi 95/5 menjadi 90/10 (v/v) dapat meningkatkan kekuatan bentur komposit untuk semua ukuran partikel serat. Penambahan serat daun nanas yang merupakan serat organik yang memiliki kandungan lignin yang berfungsi sebagai pengikat molekul - molekul selulosa dalam serat daun nanas yang dapat menyebabkan peningkatan kekakuan dan kekerasan dari komposit epoksi, dengan demikian komposit akan mampu menahan tegangan (stress) yang lebih banyak seiring dengan bertambahnya kandungan pengisi [3].

Penurunan kekuatan bentur komposit terjadi pada rasio antara matriks dan pengisi 85/15 (v/v). Hal ini disebabkan karena jumlah serat sebagai pengisi semakin banyak, sedangkan jumlah matriks semakin menurun, sehingga resin epoksi sebagai matriks tidak dapat membahasi seluruh permukaan serat sehingga akan memicu pembentukan fraksi kosong (void) didalam struktur komposit.

Pada Gambar 1 juga dapat dilihat bahwa dengan semakin kecilnya ukuran partikel maka meningkatkan kekuatan bentur komposit dengan rasio 95/5 dan 90/10 (v/v) untuk semua kandungan pengisi. Hal ini disebabkan karena semakin kecil ukuran partikel maka akan lebih mudah terdistribusi secara merata ke seluruh bagian matriks dan akan membentuk daerah 
antarfasa yang lebih luas, sehingga transfer tegangan antara matriks dan pengisi dapat terjadi [5].

\section{Karakteristik Kekuatan Bentur}

Berikut merupakan gambar hasil analisa SEM:

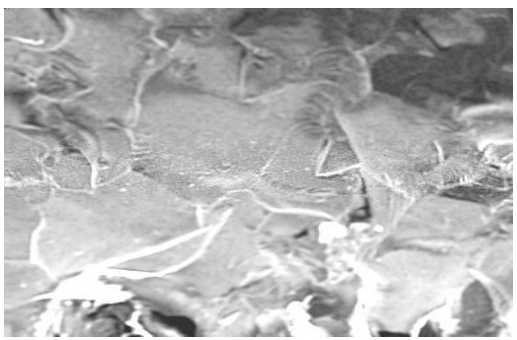

(a)

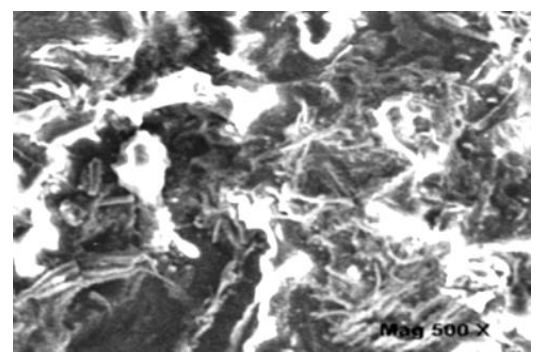

(b)

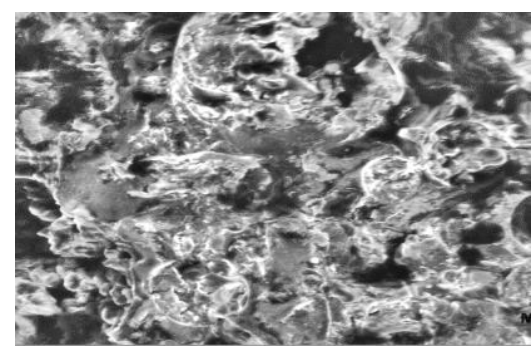

(c)

\section{Gambar 2. Hasil Analisa SEM}

(a) Epoksi Tanpa Pengisi Perbesaran 500x

(b) Komposit Epoksi - Serat Daun Nanas 30 mesh perbesaran 500x

(c) Komposit Epoksi - Serat Daun Nanas 100 mesh perbesaran $500 x$

Pada Gambar 2 (a) dapat dilihat morfologi patahan uji bentur dari epoksi murni yang memiliki struktur permukaan tidak rata dan terdapat beberapa fraksi kosong (void). Selanjutnya pada Gambar 2 (b) menunjukkan morfologi patahan dari komposit epoksi - serat daun nanas 30 mesh dengan permukaan tidak rata dan terdapat serat di dalamnya, serta terdapat beberapa rongga berukuran besar peninggalan serat yang tercabut. Sedangkan Gambar 2 (c) menunjukkan patahan komposit epoksi - serat daun nanas 100 mesh dengan bentuk permukaan yang tidak merata, dan fasa pengisi yang tersebar dengan cukup baik.

Seperti yang dapat dilihat dari Gambar 2 hasil analisa SEM yang menunjukkan penyebaran serat lebih merata untuk komposit dengan pengisi patikel 100 mesh dibandingkan dengan komposit epoksi dengan partikel pengisi 30 mesh.

\section{Kesimpulan}

Pengisi serat daun nanas mampu meningkatkan kekuatan bentur komposit, dimana kekuatan bentur maksimal diperoleh pada variasi ukuran partikel 100 mesh pada rasio matriks dan pengisi 90/10 yaitu sebesar $12,3425 \mathrm{KJ} / \mathrm{m}^{2}$ berada di atas kekuatan lentur epoksi murni yaitu sebesar 9,5061 KJ/m².

\section{Daftar Pustaka}

[1] Asbani N, Prospek Serat Daun Nanas Sebagai Bahan Baku Tekstil, Malang, Balai Penelitian Tanaman Tembakau da, Serat, 2011.

[2] Darmansyah, Evaluasi Sifat Fisik dan Sifat Mekanik Material Komposit Serat/Resin Berbahan Dasar Serat Nata De Coco Dengan Penambahan Nanofiller, Tesis, Program Pasca Sarjana Teknik Kimia UI, Depok, 2010.

[3] Hartanto L, Study Perlakuan Alkali dan Fraksi Volume Serat Terhadap Kekuatan Bending, Tarik, dan Impak Komposit Berpenguat Serat Rami Bermatriks Polyester, Skripsi, Program Sarjana Fakultas Teknik UMS, Surakarta, 2009.

[4] Hidayat P, Teknologi Pemanfaatan Serat Daun Nanas Sebagai Alternatif Bahan Baku Teksti, Skripsi, Program Sarjana Fakultas Pertanian UII, Yogyakarta, 2007.

[5] Husseinsyah S, Mostapha M, 2011, The Effect of Filler Content on Properties of Coconut Shell Filled Polyester Composites. Malaysian Polymer Journal Vol 6, No. 1 hal 87-97.

[6] Ifannossa A, A E Hadi, Analisa Kekuatan Tarik Komposit Serat Bambu Laminat Helai dan Wooven yang Dibuat Dengan Metode Manufaktur Hand Lay-Up. Skripsi, Program Sarjana Teknik Kimia ITB, Bandung, 2010.

[7] Iswanto H, Papan Partikel Dari Ampas Tebu, Skripsi, Program Sarjana Fakultas Teknik USU, Medan, 2009.

[8] Jones R M, Mechanics of Composite Materials. Washington DC, Scripta Book Company, 1975.

[9] Liu T, Morphology and Fracture Behaviour of Interacaleted Epoxy/Clay 
Nanocomposites, Journal of Applied Polymer Science, Vol 94. 1236-1244. Wiley Periodicals, Inc NY, 2004.

[10] Matthews F L, dan Rawlings R D, Composite Material Enginering and Science, London : Imperial College of Science Technology and Madicine, 1993.

[11] Mujiyono dan Didik H, Pemanfaatan Serat Daun Nanas Sebagai Penguat Material Komposit, Skripsi, Program Sarjana Fakultas Teknik UNY, Yogyakarta, 2009.

[12] Rusmiyatno F, Pengaruh Fraksi Volume Serat Terhadap Kekuatan Tarik dan Kekuatan Bending Komposit Nylon/Epoxy Resin Serat Pendek Random. Skripsi, Program Sarjana Fakultas Teknik UNS, Semarang, 2007.

[13] Subawi H, Komposit, Bandung : Dirgantara Indonesia, 2009. 